\title{
Multi-objective optimization of extraction of Tunisian Washingtonia filifera fibers for technical textile applications \\ DOI: 10.35530/IT.071.05.1716
}

MARWA BOUAZIZ
WALID CHAOUCH
SAOUSSEN ZANNEN
NATHALIE LEBLANC

MOHAMED RAGOUBI

MOHAMED BEN HASSEN

\section{ABSTRACT - REZUMAT}

\section{Multi-objective optimization of extraction of Tunisian Washingtonia Filifera fibers for technical textile applications}

The aim of this study is to investigate the effect of extraction treatment method on the properties of WPF (Washingtonia palm fibres). The employed treatment is a combined mechanical and chemical sodium hydroxide. The treatment processes was described and evaluated. The physical properties (linear density, diameter and extraction yield), and the mechanical properties (tenacity) of WPF were measured. The optimum extraction condition has been determined by a statistical study using desirability function. Obtained fibres under optimal conditions were characterized with morphological test (SEM), chemical tests (FT-IR spectra, $X$ ray diffraction) and thermal test (TGA). Fibre obtained can be employed on technical textile applications and in particular drylaid nonwoven.

Keywords: chemical properties, fibre extraction, factorial design, palm fibre, physical properties

Optimizarea multi-obiectiv a extracției fibrelor de palmier Washingtonia filifera din Tunisia pentru utilizare în textile tehnice

Scopul acestui studiu este de a investiga influența metodei de tratament prin extracție asupra proprietăților WPF (fibrele de palmier Washingtonia). Tratamentul utilizat este unul combinat, mecanic și chimic cu hidroxid de sodiu. Procesele de tratare au fost descrise și evaluate. Au fost determinate proprietățile fizice (densitatea liniară, diametrul și randamentul de extracție) și proprietățile mecanice (tenacitatea) ale WPF. Condiția optimă de extracție a fost determinată printr-un studiu statistic, care se bazează pe funcția de oportunitate. Fibrele obținute în condiții optime au fost caracterizate cu ajutorul testului morfologic (SEM), testelor chimice (spectre FT-IR, difracție de raze X) și testului termic (TGA). Fibra obținută poate fi utilizată pentru textile tehnice și, în special, la nețesutele cu fixare uscată.

Cuvinte-cheie: proprietăți chimice, extracția fibrei, proiectare factorială, fibre de palmier, proprietăți fizice

\section{INTRODUCTION}

Palm tree is a monocotyledonous plant belonging to the family of Arecaceae. This family varies greatly and has an incredible morphological diversity [1]. In recent years palm fibres have been the subject of numerous research studies with the main focus on environmental impact and biocompatibility of reinforced biocomposites. Especially, oil palm was attractive and usage of palm based fibres reinforcing polymers has undergone a dramatic increase [2, 3]. Sreekala et al. focused on oil palm fibre as an important lignocellulosic raw material for the preparation of environmentally friendly composite materials [4]. Aldousiri et al. used extracted oil palm in reinforcing of high density polyethylene (HDPE) [3]. Date palm and doum palm fibres were studied also [5-8]. Mohamed et al. focused on thermal characteristics and microstructure of a new insulation material extracted from date palm trees surface fibre [7]. Djoudi et al. studied the performance of date palm fibres reinforced plaster concrete [8]. Essabir et al. studied dynamic mechanical thermal behaviour of doum fibres reinforced polypropylene composites [5]. Zbidi et al. analysed the influence of alkaline and enzymatic treatment on the properties of doum palm fibres and composites [6]. Most of these papers were concentrated in the application of palm fibres on composite and plastic reinforced material but no attempt has been made to search for the use of palm fibres in technical textile applications, particularly dry nonwovens where specific properties of fibres (diameter, strength, stiffness) are required.

The process of extraction of fibres is of great importance, since the quality as well as the quantity of extracted fibres is strongly influenced by the methods of extraction employed [9]. The template vegetable fibres can be extracted by various methods ranging from mechanical, chemical and microbial action processes [10,11]. Several studies have revealed how various methods such as silane, alkali, peroxide, and isocyanate treatments affect the properties of natural fibres [12, 13]. Out of these methods, it has been observed that one of the simplest, most economical and effective forms of treatment with least environmental impact, is alkali treatment particularly using $\mathrm{NaOH}[14]$.

In this paper, a combined mechanical and chemical process was elaborated for the extraction of 
Washingtonia Palm Fibres (WPF). A multi-objective method based on Deming desirability function was used to optimize process yield and important fibre properties (extraction yield, fibre diameter, linear density and tenacity). This study is completed by an advanced characterization with morphological, thermal and chemical tests were made for the fibres extracted under the optimal condition. Our final objective is to evaluate the potential of using these fibres in technical textile application and in particular Drylaid Nonwoven.

\section{MATERIAL AND METHODS}

\section{Material}

Palm fibres were collected from the palm termed "Washingtonia filifer". This biomass was chosen due to their abundance in the roads and the green spaces of Tunisia as an ornament tree. The source of these fibres is the foliage of the palm tree in particular from the leaflets. The leaflet is a constituent of the leaf of the tree. Indeed, the leaf consists of several parts: the blade and the leaf axis, the latter is itself divided into a sheath encircling the stem, leafstalk and rachis bearing leaflets [1].

\section{Fiber extraction}

In this study, we first extracted the palm fibres and remove non-cellulosic materials using an alkali treatment [15] using $\mathrm{NaOH}$. An experimental design scheme was followed for optimizing the extraction process (table 1). All statistical analyses have been carried out using the statistical software minitab [16]. An experimental database has been constructed summarizing the palm extraction parameters. In this database (27 tests), we used as input variables the temperature $(T)$, the extraction time (d) and the soda concentration (C). The outputs are the extraction yield $(Y)$, the fibre diameter $(D)$, the fibre linear density (LD) and the fibre tenacity $(T)$.

Table 1

\begin{tabular}{|l|c|c|c|}
\hline \multicolumn{3}{|c|}{ FEATURES OF THE FACTORIAL DESIGN } \\
\hline \multirow{2}{*}{ Factors } & \multicolumn{3}{c|}{ Levels } \\
\cline { 2 - 4 } & $\mathbf{1}$ & $\mathbf{2}$ & $\mathbf{3}$ \\
\hline Time d (min) & 60 & 90 & 120 \\
\hline Temperature $\mathrm{T}\left({ }^{\circ} \mathrm{C}\right)$ & 80 & 90 & 100 \\
\hline Soda concentration $\mathrm{C}(\mathrm{N})$ & 1 & 2 & 3 \\
\hline
\end{tabular}

The raw fibres were immersed in a digital water bath according conditions below:

- $10 \mathrm{~g}$ of leaflets of palm tree;

- Liquor ratio = $1 / 40$;

- Temperature $\mathrm{T}\left({ }^{\circ} \mathrm{C}\right)$ ranges from $80^{\circ} \mathrm{C}$ to $100^{\circ} \mathrm{C}$;

- Duration d $(\mathrm{min})$ of treatment ranges from 60 to 120 min;

- Sodium hydroxide concentration $\mathrm{C}(\mathrm{N})$ ranges from $1 \mathrm{~N}$ to $3 \mathrm{~N}$.
The factor levels were chosen based on literature first and thereafter adjusted based on our preliminary tests results. Indeed, in most of the references e.g. [17-18] $100^{\circ} \mathrm{C}$ temperature is the most widely adopted value for palm fibre extraction. In our study it was proved respectively that: at $80^{\circ} \mathrm{C}$ the extraction is no longer possible and at $120^{\circ} \mathrm{C}$ the fibre was hydrolysed [19]. After treating the foliages of palm leaves, they were rinsed in hot water several times, then they were mechanically brushed using a metallic brush; the brush is moved in the longitudinal direction of the edges of sheets in order to separate fibres. Finally, the obtained fibres are dried to the ambient air for $48 \mathrm{~h}$. The treated fibres were physically, mechanically and chemically characterized in order to measure their properties. The tests carried out on a batch of conditioned fibres in a normal atmosphere (relative humidity: $65 \% \pm 4 \%$, temperature: $20^{\circ} \mathrm{C} \pm 2^{\circ} \mathrm{C}$ ).

\section{Physical fiber tests}

Yield of fibers (R\%) is measured by the weight percentage of final mass of the fibres after extraction process (Mf) with respect to that of the palm folioles before extraction process $(\mathrm{Mi})$. The measurement of the mass is performed using the gravimetric method in accordance with standard NF G 08-001.

$$
R(\%)=\frac{M f}{M i} \times 100
$$

Diameter was measured using an optic microscope Leica, in accordance with the French standard NF G 07-004 (1983). The test is carried out on 300 fibres chosen at random.

The linear density was measured by weighing fibres of known lengths using the gravimetric method and according to the standard ISO 1973(1995).

The tensile tests of the fibres were performed under standard conditions with a LLOYD dynamometer according to NF G07-002 standard. The length between clamps was taken equal to $20 \mathrm{~mm}$; the crosshead speed was $20 \mathrm{~mm} / \mathrm{min}$ and the load was measured using a $100 \mathrm{~N}$ load. The values are reported as the means of 50 measurements.

The density measurement of the WPF was carried out using a gas pycnometer which is recognized as one of the most reliable techniques for obtaining density. That was made using The AccuPyc II 1340.

\section{Morphological fibre tests}

The technical WPF obtained are morphologically characterized. The specimens were observed using a Scanning Electron Microscope (SEM) to characterize the morphology of treated and untreated fibres.

\section{Thermal and chemical fibre tests}

Crystal phase characterization was carried out using XRD and ATR -FTIR analyses. X-Ray Diffraction (XRD) analyses patterns were recorded using a D8 Discover diffractometer (Bruker) equipped with a LynxEye detector. Cu Ka radiation $(\lambda=1.541 \AA$ ) with a tube voltageand amperage set at $40 \mathrm{kV}$ and $40 \mathrm{~mA}$ respectively was used as reference configuration. 
Compressed fibre samples were placed onto a flatfrosted glass and analysed at room temperature with a step of $0.04^{\circ}(2 \theta)$ and a dwell time of $0.5 \mathrm{~s}$ from 3 to $60^{\circ}(2 \theta)$. The use of XRD counts offers an easy way to evaluate the crystalline index of fibres, which can be calculated from Equation below [20]:

$$
\operatorname{Crl}(\%)=\frac{I_{002}-I_{a m}}{I_{002}} \times 100
$$

where $\mathrm{Crl}(\%)$ is the crystalline index, $I_{002}$ - the maximum intensity of the 002 lattice diffraction plane at a $2 \theta$ angle between $22^{\circ}$ and $23^{\circ}, I_{a m}$ - the intensity diffraction at an angle $2 \theta$ close to $18^{\circ}$ representing amorphous materials in plant fibres.

ATR-FTIR spectra of the WPF were recorded using a Nicolet iS10 Thermo Scientific connected to an ATR accessory. The analysis of the samples is carried out on the surface and up to a beam penetration depth of a few micrometres.

The thermal stability of fibres was evaluated by thermo gravimetric analysis (TGA). The WPF were placed in a NETZSCH TG 209 F1 Libra thermo gravimetric, under argon and were heated up to $800^{\circ} \mathrm{C}$, with a heating rate of $5^{\circ} \mathrm{C} / \mathrm{min}$.

\section{RESULTS AND DISCUSSION}

\section{Effect of the treatment processes on the} physical properties of WPF fibres

To better visualize the effect of extraction conditions on physical properties of palm fibres, the effects of the main parameters were graphically illustrated. As shown in figure 1, the fibre's linear density decreases when aggravating treatment conditions (concentration of soda, temperature, duration of treatment). In fact, the linear density of untreated fibres amounts to 41 Tex whereas that of treated fibres ranges from 40 to 13 Tex. This reduced mass per unit length could be attributed to the removal of waxy and gummy materials deposited on fibres. The lower linear density was obtained under $\mathrm{T}=100^{\circ} \mathrm{C}$, treatment duration of 120 min and soda concentration of $3 \mathrm{~N}$. This confirms the result obtained of diameter.

Moreover, as shown in diameter plot (figure 2), the diameter revealed the same behaviour with linear density against hydroxide treatment. In fact, the untreated fibres present a diameter of $511 \mu \mathrm{m}$. However the diameter of treated fibres ranges from 384 to $109 \mu \mathrm{m}$. This increased fibre fineness could be attributed to the removal of gummy materials present on the surface of fibres and between the ultimate fibres [21]. The lower diameter was obtained in the combination $\left(100^{\circ} \mathrm{C}, 120 \mathrm{~min}\right.$ and $\left.3 \mathrm{~N}\right)$ which confirms result obtained from the linear density analysis. In order to obtain a fine structure, extraction conditions need to be cruel. In fact, treatment duration, soda concentration, and temperature, favour the separation of WPF and their cleanings while removing impurities. These impurities, such as pectin, lignin, hemicelluloses, wax, and fat materials, held the fibres in bundles. This reduction in fibres fineness (diameter and linear density) could be proved by the results shown for the yield extraction.

As revealed in main effect plot for yield (figure 3), the yield decreased when engraving extraction conditions. The highest extraction yield is obtained while proceeding in the least severe conditions of treatment which confirms the important fineness of fibres resulted in this case (diameter $=384 \mu \mathrm{m}$; linear density $=40$ Tex). Therefore, in such condition, the alkalization was not effective to remove foreign substances bundling fibres. When temperature, soda concentration and duration of treatment increased, the elimination of non-cellulosic components became faster and more important, however yield decreased and consequently fineness.

\section{Effect of the treatment processes on the mechanical properties of WPF fibres}

The mechanical properties of textile fibres are very interesting properties. They define the behaviour of fibres during different transformation processes and the properties of the finished products made from these fibres. Depending on the significance of their characteristics, the lignocellulosic fibres such as those of the palm fibre can be used in various applications [22]. The tenacity is defined by the ratio of the maximum load a specimen can support and its linear density. As shown in the main effect plot for tenacity (figure 4), the tenacity of fibres has changed after the

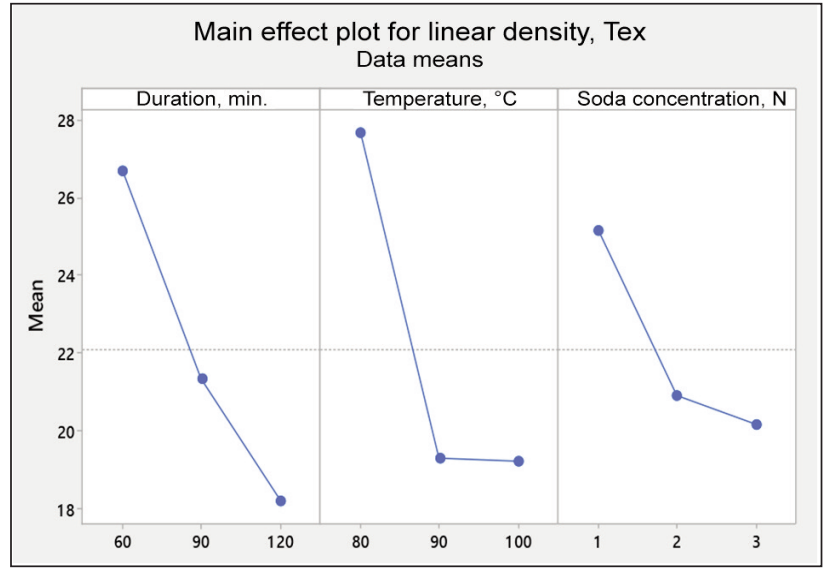

Fig. 1. Main effect plot for linear density

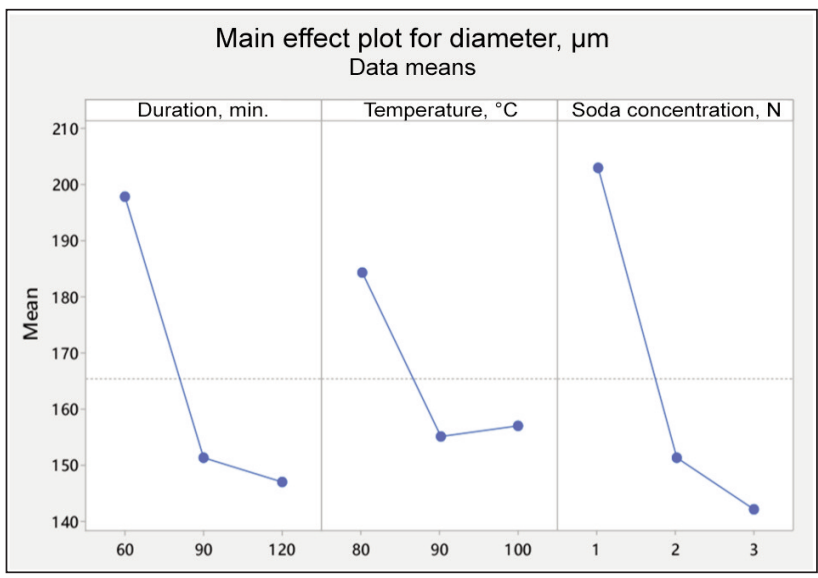

Fig. 2. Main effect plot for diameter 


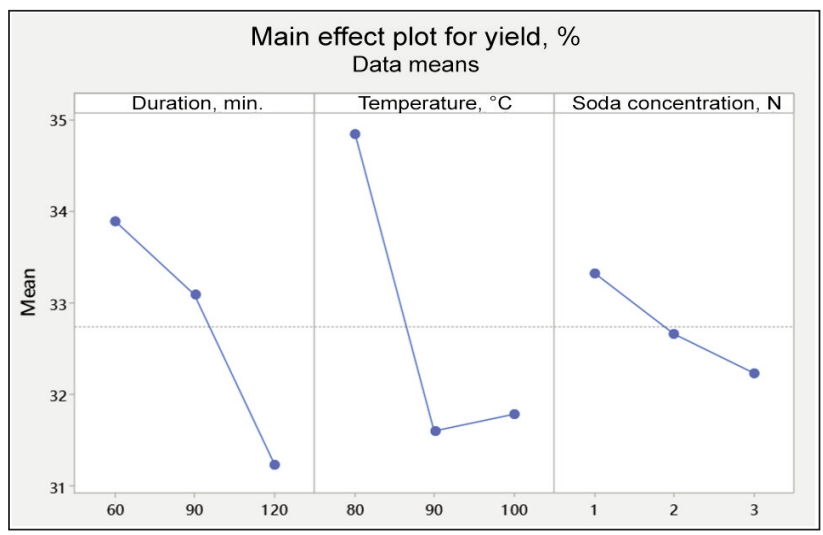

Fig. 3. Main effect plot for Yield

alkaline treatment. The fibres obtained at the mild condition of treatment (temperature, soda concentration and duration) have a low tenacity while the removal of impurities from fibres was ineffective in this case. When aggravating treatment conditions, the tenacity was improved. This can be explained by the fact that the soda treatment in this condition, favoured arrangement of macromolecular chains of cellulose while eliminating lignin and hemicelluloses deposited on the fibre. This increases the crystallinity of the fibres and subsequently their resistance [23]. In fact, the fibres tenacity achieved a threshold (53, $55 \mathrm{cN} / \mathrm{Tex}$ ) in the combination $\left(2 \mathrm{~N}, 100^{\circ} \mathrm{C}\right.$ and 90 $\min )$. When aggravated the extraction conditions, the tenacity of fibres declined $(<23.5 \mathrm{cN} / \mathrm{Tex})$ as a result of destruction of cellulosic structure and greater impurity removal.

\section{Degree of control factors influence on the physical and mechanical properties}

In order to conclude on the importance of extraction conditions, a statistical analysis of the effect of temperature, soda concentration and duration of the treatment on the various properties was developed. The $p$-value is used in hypothesis tests to help you decide whether to reject or accept a null hypothesis. The $p$-value is the probability of obtaining a statistic test that is at least as extreme as the actual calculated value, if the null hypothesis is true. A commonly used cut-off value for the $p$-value is 0.05 . For example, if the calculated $p$-value of a test statistic is less than 0.05 , you reject the null hypothesis. This null hypothesis in our case is the factor that has no

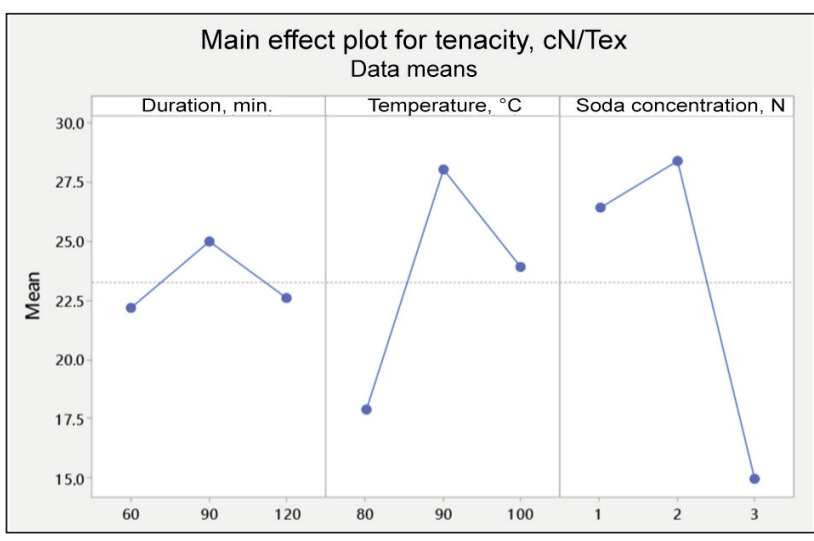

Fig. 4. Main effect plot of tenacity

significant influence on the fibbers' property [22, 24] Results of the p-values are shown in table (2).

From this table, we can notice that the most influencing parameter on the measured properties was temperature and duration which was predominant.

\section{Optimization of treatment conditions}

In order to optimize the treatment conditions we have used the desirability functions in which we took into account the target " $Y$ target", and the importance of every property "Yi" in the definition of global desirability [25]. In this study, it was used two types of desirability functions "di": desirability function to maximize and to minimize. Thus, to maximize a property "Yi", such as the yield, strength and elongation, the desirability function had to be used, where di was calculated as follows:

$$
\begin{aligned}
& d=0 \text { if } Y_{i} \leq Y_{\min } ; \\
& d_{i}=\left[\frac{Y_{i}-Y_{\min }}{Y_{\text {target }}-Y_{\min }}\right] \text { if } Y_{\min } \leq Y_{i} \leq Y_{\text {target }} ; \\
& d_{i}=1 \text { if } Y_{i} \geq Y_{\text {target }}
\end{aligned}
$$

To minimize a property "Yi", the desirability function had to be used, where $d_{i}$ was calculated as follows:

$$
\begin{aligned}
& d=1 \text { if } Y_{i} \leq Y_{\text {target }} ; \\
& d_{i}=\left[\frac{Y_{i}-Y_{\text {max }}}{Y_{\text {target }}-Y_{\text {max }}}\right] \text { if } Y_{\text {target }} \leq Y_{i} \leq Y_{\text {max }} ; \\
& d_{i}=0 \text { if } Y_{i} \geq Y_{\text {max }}
\end{aligned}
$$

For each property affecting the global desirability, it was calculated the satisfaction degree "dg" and we

\begin{tabular}{|l|c|c|c|c|}
\hline \multicolumn{5}{|c|}{ P-VALUES MEANING } \\
\hline Dependent variables & Linear density $($ Tex $)$ & Diameter $(\boldsymbol{\mu})$ & Yield $(\%)$ & Tenacity $(\mathbf{c N} /$ Tex $)$ \\
\hline Soda concentration $(N)$ & $\begin{array}{c}\text { significant influence } \\
(p<0.05)\end{array}$ & $\begin{array}{c}\text { significant influence } \\
(p<0.05)\end{array}$ & $\begin{array}{c}\text { insignificant influence } \\
(p>0.05)\end{array}$ & $\begin{array}{c}\text { significant influence } \\
(p<0.05)\end{array}$ \\
\hline Temperature $\left({ }^{\circ} \mathrm{C}\right)$ & $\begin{array}{c}\text { significant influence } \\
(p<0.05)\end{array}$ & $\begin{array}{c}\text { insignificant influence } \\
(p>0.05)\end{array}$ & $\begin{array}{c}\text { significant influence } \\
(p<0.05)\end{array}$ & $\begin{array}{c}\text { insignificant influence } \\
(p>0.05)\end{array}$ \\
\hline Duration $(\mathrm{min})$ & $\begin{array}{c}\text { significant influence } \\
(p<0.05)\end{array}$ & $\begin{array}{c}\text { significant influence } \\
(p<0.05)\end{array}$ & $\begin{array}{c}\text { significant influence } \\
(p<0.05)\end{array}$ & $\begin{array}{c}\text { insignificant influence } \\
(p>0.05)\end{array}$ \\
\hline
\end{tabular}


attributed a relative weight to indicate the property's importance. These different satisfaction degrees were grouped by using the Derringer and Suich desirability function [26] defined as follows:

$$
d_{g}=\sqrt[w]{d_{1}^{W_{1}} \times d_{1}^{W_{2} \times \ldots \times d_{1}^{w_{n}}}}
$$

where $d_{i}$ is the individual property's desirability function $Y_{i} i \in[1, \ldots, n], w_{i}$ - the weight of the property $Y_{i}$ in the "dg" desirability function, $w-$ the sum of $w_{i}$ and $n-$ the number of properties. The compromise between the properties (minimize fibre linear density and diameter, maximize yield and tenacity) was better when "dg" increased; it became "perfect" when "dg" was equal to 1. When the satisfaction degree "di" of the property $Y_{i}$ was equal to 0 , the response had a value outside of the tolerance of the function "dg" was equal to 0 and so the compromise was rejected. To define the desirability function, we had to set the objective for every property. These different objectives are reported in table 3 . The results of desirability for each property and the optimum values for the independent variables are presented in table 4 and table 5 .

Table 3

\begin{tabular}{|l|c|c|c|}
\hline \multicolumn{4}{|c|}{ THE OPTIMUM LEVELS OF PROPERTIES } \\
\hline $\begin{array}{c}\text { Dependent } \\
\text { variables }\end{array}$ & Objective & Min & Max \\
\hline Linear density $($ Tex $)$ & Minimize & - & 30 \\
\hline Diameter $(\mu \mathrm{m})$ & Minimize & - & 250 \\
\hline Yield $(\%)$ & Maximize & 28 & - \\
\hline Tenacity $(\mathrm{cN} / \mathrm{Tex})$ & Maximize & 18 & - \\
\hline
\end{tabular}

Table 4

\begin{tabular}{|l|c|c|c|}
\hline \multicolumn{4}{|c|}{ DESIRABILITY VALUES FOR THE DEPENDENT } \\
VARIABLES \\
\hline $\begin{array}{c}\text { Dependent } \\
\text { variables }\end{array}$ & Value & $\begin{array}{c}\text { Desirability } \\
\mathbf{d}_{\mathbf{i}}(\%)\end{array}$ & Weight \\
\hline Linear density $($ Tex $)$ & 17.34 & 100 & 1 \\
\hline Diameter $(\mu \mathrm{m})$ & 128.84 & 100 & 1 \\
\hline Yield $(\%)$ & 32.07 & 82 & 1 \\
\hline Tenacity $(\mathrm{cN} /$ Tex $)$ & 30.73 & 100 & 1 \\
\hline Global desirability $\left(\mathrm{d}_{\mathrm{g}}\right)$ & - & 95.04 & - \\
\hline
\end{tabular}

Note: $d_{i}$ denotes individual desirability of dependent variables (linear density, diameter, yield, and strength).

Table 5

OPTIMUM VALUES FOR THE INDEPENDENT VARIABLES

\begin{tabular}{|l|c|c|}
\hline \multicolumn{1}{|c|}{ Value } & $\begin{array}{c}\text { Normalized } \\
\text { value }\end{array}$ & Real value \\
\hline Temperature $\left({ }^{\circ} \mathrm{C}\right)$ & 3 & 100 \\
\hline Soda concentration $(\mathrm{N})$ & 2 & 2 \\
\hline Duration $(\mathrm{min})$ & 2 & 90 \\
\hline
\end{tabular}

The statistical study determined the optimum treatment conditions which are: $100^{\circ} \mathrm{C}$ as temperature, $2 \mathrm{~N}$ as soda concentration and during $90 \mathrm{~min}$.

\section{Characterization of fibres treated with optimum conditions}

\section{Morphological properties}

Figure 5, a and 6, a represent the longitudinal views of untreated and treated WPF respectively. As shown in the figure, the untreated fibres were covered by gummy and waxy material on their surfaces. After the combined treatment, SEM micro-graphics show an improvement in surface morphology. Application of soda treatment helped removing large impurities amount of from the fibre surface and causes fibrillation. It was observed that a dimensional variation of the fibre upon transverse cut (figures $5, b$ and 6,b). The structure of the technical WPF fibre was similar to that of natural fibres: sisal, esparto [5]. It represented a natural composite in which the ultimate microfibrils of cellulose constituted the reinforcement and the ligneous substances constituted the matrix [17]. Ray et al. [27] reported that the progressive increase in the time of treatment causes the reduction of the mass of the fibre until stabilization; that is, the treatment eliminates only the residual impurities and does not attack microfibrils of cellulose. As shown in figure $6, b$, the treatment eliminated waxy substances present on the surface of untreated fibres. The treatment decreased the amorphous cellulose quantity to the detriment of the crystalline quantity [28]. According to the morphological survey made date palm fibre (DPF), the external layer is the lignin [28].

Figure 6 shows an increase of pore number in fibres after alkali treatment. The result agrees with previous studies conducted on the date palm fibre (DPF) [28]. By using aqueous solution, a large number of regularly distributed holes appeared on the fibre surface. These holes were caused by the reaction between the aqueous solution and the outer layer of fibres; these holes originated from the removal of the fatty deposit already existing on the surface. This large number may also tend to decrease the mechanical properties of single fibres.

\section{Physical properties}

Similar to other lignocellulosic fibres, the chemical treatments used in this study induced variation in the fibbers' physicochemical properties. The density of WPF treated at optimum conditions was found between $1.50 \mathrm{~g} / \mathrm{cm}^{3}$ and $1.53 \mathrm{~g} / \mathrm{cm}^{3}$, very close to that of other natural fibres: the ramie, the jute, the flax, etc. Table 6 summarizes the densities for the natural fibres. The treatment increased the density of WPF. The lower density of untreated palm fibre when compared to treated fibres could be attributed to large fibre diameter after treatment, which resulted in an increase in the diameter of the central void (lumen). Al-Khanbashi et al. and Josef et al. reported similar concerns with date palm fibre (DPF) and sisal 

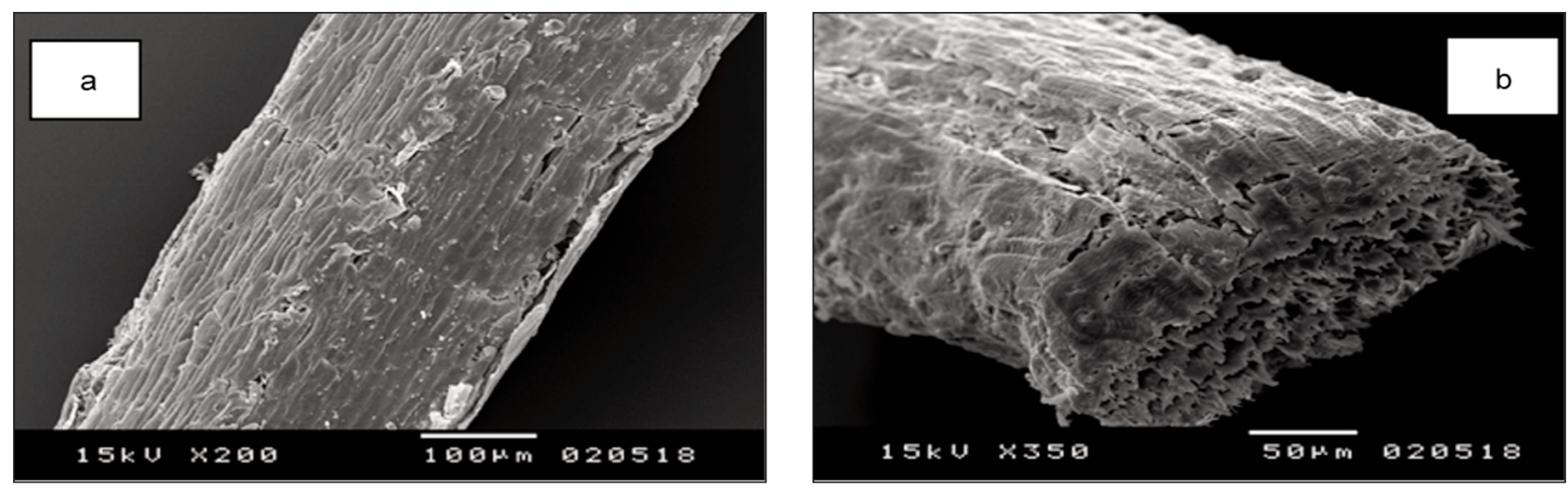

Fig. 5. SEM of untreated WPF (a) longitudinal and $(b)$ cross-sectional views
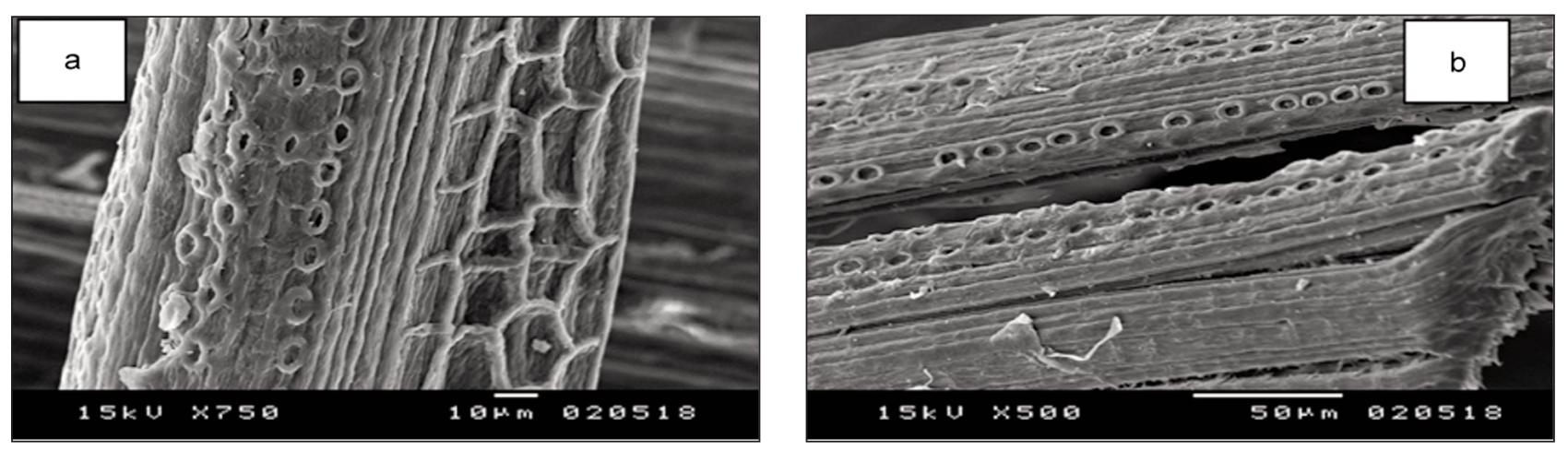

Fig. 6. SEM of treated WPF at the optimum conditions (a) longitudinal and (b) cross- sectional views

Table 6

\begin{tabular}{|l|c|}
\hline \multicolumn{2}{|c|}{ DENSITIES FOR SOME NATURAL FIBERS [32] } \\
\hline \multicolumn{1}{|c|}{ Fibers } & Density $\left(\mathbf{g} / \mathbf{c m}^{\mathbf{3}}\right)$ \\
\hline Banana tree & $1.4-1.45$ \\
\hline Sisal & 1.45 \\
\hline Jute & 1.44 \\
\hline Ramie & 1.56 \\
\hline Flax & 1.54 \\
\hline Alfa & 1.35 \\
\hline Agave Americana & 1.36 \\
\hline Untreated WPF & 1.15 \\
\hline Treated WPF & $1.50-1.53$ \\
\hline
\end{tabular}

fibres [28-29]. The alkali treatment affected the central voids and contributed to the gradual elimination of microvoids, which may have resulted in an increase in fibre density.

The linear density values obtained from the various palm fibre types and other natural fibres are presented in table 7. It was observed that the experimental result for linear density is in good agreement with the statistical result (table 4). It was varied from 41 Tex of raw material to 19 Tex of optimum treated WPF. Their linear densities are less than fibres extracted from leafstalk of doum palm [4] and typha fibres [30]. But they are close to fibre extracted from esparto [31].
Table 7

LINEAR DENSITY AND DIAMETER FOR SOME NATURAL FIBERS [33-34]

\begin{tabular}{|l|c|c|}
\hline \multicolumn{1}{|c|}{ Fiber } & $\begin{array}{c}\text { Linear density } \\
(\text { Tex })\end{array}$ & $\begin{array}{c}\text { Apparent } \\
\text { diameter }(\boldsymbol{\mu m})\end{array}$ \\
\hline $\begin{array}{l}\text { Doum palm leafstalk } \\
\text { fiber }\end{array}$ & 45.67 & 315.4 \\
\hline Kenaf & 12 & 123 \\
\hline Typha fiber & 31.3 & 205.1 \\
\hline Esparto & 21.95 & - \\
\hline Untreated WPF & 41 & 511 \\
\hline Treated WPF & 19 & 132 \\
\hline
\end{tabular}

Treated WPF had an apparent diameter of approximately $131 \mu \mathrm{m}$. The apparent diameter of untreated WPF was $511 \mu \mathrm{m}$. The exterior area of the fibre increased due the elimination of impurities of lignin and hemicelluloses. Equally the experimental result for diameter is in good agreement with the statistical result (table 4). The apparent diameter of technical WPF approximated that of the other natural fibres; it was always lower than $1000 \mu \mathrm{m}$ and close to that of the kenaf fibre.

\section{Mechanical properties}

Non cellulosic material, constituting a part of natural fibres [35], could be removed by appropriate alkali treatments, which affect the tensile characteristic of 
the fibre [36]. To assess this hypothesis, tensile properties of the chemically extracted fibres were determined by a LLOYD LRX tensile tester. Figure 7 illustrates load elongation diagram of treated WPF at optimum condition and untreated WPF. We notice that treatment improved the mechanical properties of WPF markedly the tensile strength but not the elongation to the break. There was an increase in the breaking strength to an average of almost $50 \%$. It could be linked to the increase in the degree of arrangement of the cellulose (crystalline regions), the reduction of the lignin rate in the fibre, the removal of the amorphous matter and the lumen reduction of fibres. This disagrees with the work of Sghaier et al. who proved an improvement in tensile strength as well as elongation to break [17].

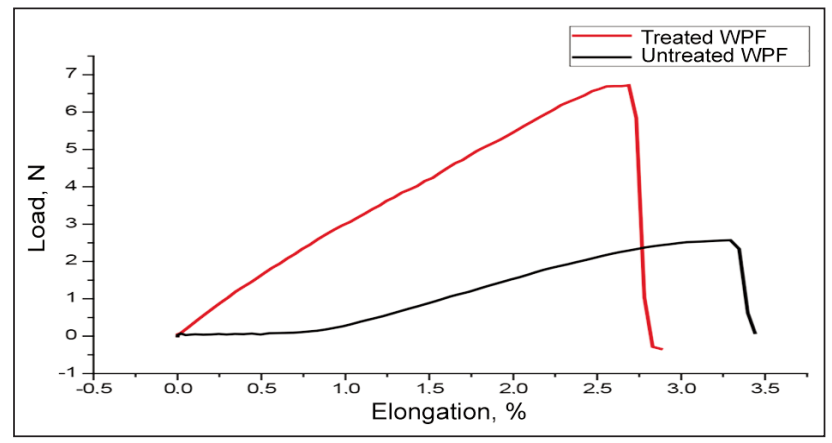

Fig. 7. Load elongation diagrams for treated WPF

The quality of any textile fibre largely depends on its two important properties, namely fineness and tenacity. The WPF have important mechanical properties. The WPF obtained have a better tenacity than the other vegetable fibres such as cotton, jute and agave Americana $L$ (table 8). We note that the experimental result of tenacity is in good agreement with the statistical analyses (table 4).

Table 8

TENACITY AND ELONGATION OF VEGETABLE FIBER [32-33]

\begin{tabular}{|l|c|c|}
\hline \multicolumn{1}{|c|}{ Fiber } & $\begin{array}{c}\text { Elongation } \\
\text { (\%) }\end{array}$ & $\begin{array}{c}\text { Tenacity } \\
\text { (cN/Tex) }\end{array}$ \\
\hline Cotton & $7-8$ & $26-44$ \\
\hline Jute & $1.5-1.8$ & $26-51$ \\
\hline Alfa & $1.5-2.4$ & - \\
\hline Agave americana.L & 49.64 & 28.3 \\
\hline Untreated WPF & 4.5 & 13.2 \\
\hline Treated WPF & 2.9 & 34 \\
\hline
\end{tabular}

\section{$X R D$ analysis}

The crystallographic structure and chemical composition were carried out by X-ray diffraction technique, for treated and untreated fibres. The XRD patterns of the treated and untreated WPF are shown in figure 8. It can be clearly observed that the diffraction peaks appear in the pattern corresponding to crystalline phase. The characteristic main peaks of cellulose at $2 \theta=16^{\circ}, 23.43^{\circ}$ and $34.5^{\circ}$ can be observed. These peaks are indicative of the presence of cellulose [37]. According to several authors [38-39], these two peaks can be attributed to cellulose I and IV, both having a monoclinic structure. The XRD pattern of treated WPF has similar features to that of untreated WPF but with a higher diffraction peak at $22.90^{\circ}$ which may be attributed a crystalline cellulosic peak. The height of this peak can be due to the contribution of both the amorphous and the crystalline fractions according Sreenivasan et al. [35]. The increase in concentration of $\mathrm{NaOH}$ treatment increased the crystallinity index due to the removal of amorphous phase. Similar effects were observed for sisal fibre [40]. This is supported by the improvement in crystalline index $(\mathrm{Crl})$ values (38\% for untreated fibre and $62 \%$ for treated fibres) which was calculated according to the method of Segal. This value is higher than that of the Wrighitia tinctoria seed fibre $(49.2 \%)$ and ramie $(58 \%)$; it is close to the value for cotton $(60 \%)$ and smaller than that for raffia textilis $(64 \%)$, sisal $(71 \%)$, jute $(71 \%)$, flax $(80 \%)$ and hemp $(88 \%)$ [39, 41-43].

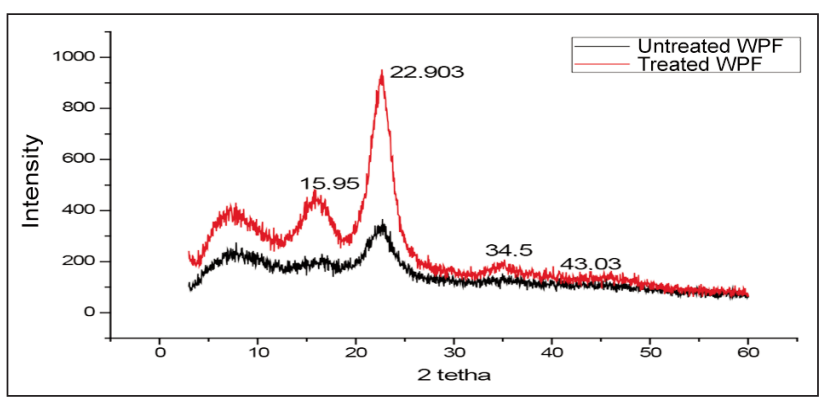

Fig. 8. X-ray diffraction spectra of raw and treated WPF

\section{Fourier transforms infrared spectrometry}

The chemical structure of WPF and the effects of $\mathrm{NaOH}$ treatment on the fibre's surface were also studied using FTIR. The FTIR spectra for WPF are presented in figure 9 . The band positions vary between studies. When the variability of the position is taken into account, the bands at $3400 \mathrm{~cm}^{-1}$ and $760 \mathrm{~cm}^{-1}$ can be attributed to cellulose $\mathrm{I}_{\beta}[44,45]$. The bands at $1740 \mathrm{~cm}^{-1}$ and $1510 \mathrm{~cm}^{-1}$ are attributed to lignin [44]. The $\mathrm{CH}$ stretch at $2838 \mathrm{~cm}^{-1}$ and

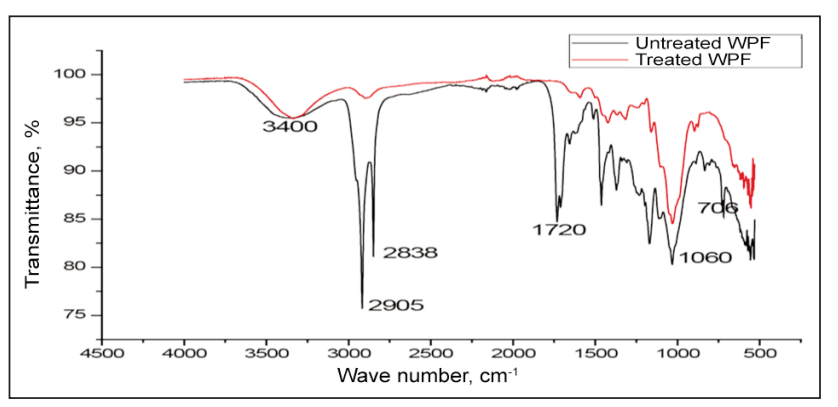

Fig. 9. FT-IR spectra's of raw and treated WPF 
$2905 \mathrm{~cm}^{-1}$ are present in the spectrum. The carbonyl band at $1720 \mathrm{~cm}^{-1}$ can be seen in the spectrum. The band at $1720 \mathrm{~cm}^{-1}$ is also attributed to the $\mathrm{C}=\mathrm{O}$ stretch of the acetyl groups of hemicelluloses [35-46]. The band at $1060 \mathrm{~cm}^{-1}$ is a stretching vibration of $\mathrm{C}-\mathrm{O}$.

\section{Thermal stability}

The thermal properties of palm fibre were carried out by TGA under argon in the range of $25-800^{\circ} \mathrm{C}$ at a heating rate of $5^{\circ} \mathrm{C} / \mathrm{min}$. The TGA curve for WPF is presented in figure 10 .

The fibre mass decreased from about 93\% (at $100^{\circ} \mathrm{C}$ ) to $89 \%$ (at $250^{\circ} \mathrm{C}$ ) and to $32 \%$ (at $350^{\circ} \mathrm{C}$ ). Different regions can be associated with the loss of retained water at $100^{\circ} \mathrm{C}$, hemicellulose degradation in the $200-260^{\circ} \mathrm{C}$ region, cellulose degradation at $240-350^{\circ} \mathrm{C}$ and lignin degradation at $280-500^{\circ} \mathrm{C}$ $[43,45]$. Between 100 and $250^{\circ} \mathrm{C}$, degradation turned the ligno-cellulosic fibre into a brownish colour material, losing its strength, although this was not quantified. At higher temperatures, up to $500^{\circ} \mathrm{C}$, carbonization occurred with accentuated loss of material. The degradation reactions of lignin and cellulose become exothermic at about 270 and $300^{\circ} \mathrm{C}$, respectively. Pyrolysis of a cellulose occurred at about $300^{\circ} \mathrm{C}$ and of lignin at about $400^{\circ} \mathrm{C}$, while hemicellulose decomposed at a considerably lower temperature [36]. The TGA curve profile for the untreated fibres was similar to previous work [19].

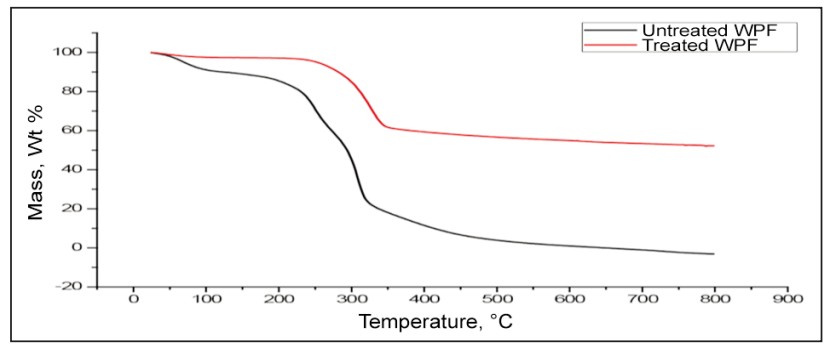

Fig. 10. Thermogram (TGA) curve of untreated and treated WPF

\section{CONCLUSION}

Vegetation associated with agriculture and forestry is a large source for extracting fibres, which has been largely under-utilized. The Washingtonia palm fiber (WPF) is vegetable fibre which derives from of the palm "Washingtonia filifera". This plant does not need particular attention on cultivating them but their maintenance of the plantations produces a great amount of waste material. For that reason, we aimed to valorise it. The process of extraction of WPF results in an excellent quality of fibre. The optimum extraction conditions were found to be the average parameters of the extraction process with $2 \mathrm{~N}$ soda concentration and $100^{\circ} \mathrm{C}$ for $90 \mathrm{~min}$. In this study we have investigated the physical, mechanical, morphological chemical and thermal properties of this fibre. The treatment eliminated the residual impurities. Therefore it decreased the diameter, the linear density and increased the density of fibres. WPF presented a natural composite in which fibrils of cellulose constituted the reinforcement and the ligneous and gummy substances constituted the matrix. The fibres had some morphological properties similar to those of other natural fibres such as the esparto. The FTIR spectra revealed the cellulosic structure of these fibres and their modification after chemical treatment. This change in structure is due to the increase of the cellulose amount exposed on the fibre surface, which increases the number of possible reaction sites $(\mathrm{OH}$ and $\mathrm{CH}$ groups). X-ray diffraction analysis performed to evaluate the variation of crystallinity index in dependence of the treatment, showed how the treatment improved the properties of the fibre. Finally, it is possible to consider the alkali treatment as a useful step in the production of WPF, since a significant improvement in quality was observed which opens the opportunity for using this kind of natural fibres in eco-friendly and low cost textile materials, in particular nonwoven materials.

\section{REFERENCES}

[1] Romain, T., Anatomie comparée des palmiers: Identification-assistée par ordinateur, Applications en paléobotanique et en archéobotanique, 2011, available at: https://www.researchgate.net/publication/215892059_ Anatomie_comparee_des_palmiers_Identification-assistee_par_ordinateur_Applications_en_paleobotanique_ et_en_archeobotanique [Accessed July 3rd 2019]

[2] Shinoj, S., Visvanathan, R., Panigrahi S., Kochubabu, M., Oil palm fiber (OPF) and its composites: A review, In: Ind. Crops Prod., 2011, 33, 1, 7-22

[3] Aldousiri, B., Alajmi, M., Shalwan, A., Mechanical Properties of Palm Fibre Reinforced Recycled HDPE, 2013, Available at: https://www.hindawi.com/journals/amse/2013/508179/ [Accessed October 21 2017]

[4] Sreekala, M.S., Kumaran, M.G., Thomas, S., Oil palm fibers: Morphology, chemical composition, surface modification, and mechanical properties, In: J. Appl. Polym. Sci., 1997, 66, 5, 821-835

[5] Essabir, H., Elkhaoulani, A., Benmoussa, K., Bouhfid, R., Arrakhiz, F.Z., Qaiss, A., Dynamic mechanical thermal behavior analysis of doum fibers reinforced polypropylene composites, In: Mater. Des., 2013, 51, Supplement C, 780-788

[6] Zbidi, F., Sghaier, S., Nejma, M.B., Zidi, M., Influence of Alkaline and Enzymatic Treatments on the Properties of Doum Palm Fibres and Composite, Available at: https://scialert.net/fulltext/?doi=jas.2009.366.371 [Accessed July $\left.2^{\text {nd }} 2019\right]$ 
[7] Ali, M.E., Alabdulkarem, A., On thermal characteristics and microstructure of a new insulation material extracted from date palm trees surface fibers, In: Constr. Build. Mater., 2017, 138, 276-284

[8] Djoudi, A., Bali, A., Debicki, G., Performance of date palm fibres reinforced plaster concrete, 2012

[9] Yang, Q., et al., Kenaf Bast Fiber Treatment for Nonwoven Fabrics, 2001, Available at: https://www.researchgate. net/publication/239272411_Kenaf_Bast_Fiber_Treatment_for_Nonwoven_Fabrics [Accessed July $2^{\text {nd }} 2019$ ]

[10] Yu, H., Yu, C., Influence of various retting methods on properties of kenaf fiber, In: J. Text. Inst., 2010, 101, 5, 452-456

[11] Amel, B.A., Paridah, M. T., Sudin, R., Anwar, U.M.K., Hussein, A.S., Effect of fiber extraction methods on some properties of kenaf bast fiber, In: Ind. Crops Prod., 2013, 46, 117-123

[12] Sgriccia, N., Hawley, M.C., Misra, M., Characterization of natural fiber surfaces and natural fiber composites, In: Compos. Part Appl. Sci. Manuf., 2008, 39, 10, 1632-1637

[13] Joseph, K., Thomas, S., Pavithran, C., Effect of chemical treatment on the tensile properties of short sisal fibrereinforced polyethylene composites, In: Polymer, 1996, 37, 23, 5139-5149

[14] Xiao, B., Sun, X.F., RunCang, S., Chemical, structural, and thermal characterizations of alkali-soluble lignins and hemicelluloses, and cellulose from maize stems, rye straw, and rice straw, In: Polym. Degrad. Stab., 2001, 74, 2 , 307-319

[15] Alawar, A., Hamed, A.M., Al-Kaabi, K., Characterization of treated date palm tree fiber as composite reinforcement, In: Compos. Part B Eng., 2009, 40, 7, 601-606

[16] Evans, R., Newman, R.H., Roick, U.C., Suckling, I.D., Wallis, A.F.A., Changes in Cellulose Crystallinity During Kraft Pulping. Comparison of Infrared, X-ray Diffraction and Solid State NMR Results, In: Holzforsch. - Int. J. Biol. Chem. Phys. Technol. Wood, 2009, 49, 6, 498-504

[17] Sghaier, S., Zbidi, F., Zidi, M., Characterization of Doum Palm Fibers After Chemical Treatment, In: Text. Res. J., 2009, 79, 1108-1114

[18] Zannen, S., Ghali, L., Halimi, M.T., Hssen, M.B., Effect of Chemical Extraction on Physicochemical and Mechanical Properties of Doum Palm Fibres, In: Adv. Mater. Phys. Chem., 2014, 4, 10, 203

[19] Arrakhiz, F.Z., El Achaby, M., Benmoussa, K., Bouhfid, R., Essassi, E.M., Qaiss, A., Evaluation of mechanical and thermal properties of Pine cone fibers reinforced compatibilized polypropylene, In: Mater. Des., 2012, 40, 528-535

[20] Zannen, S., Ghali, L., Halimi, M.T., Hassen, M.B., Effect of Combined Chemical Treatment on Physical, Mechanical and Chemical Properties of Posidonia Fiber, In: Adv. Mater. Phys. Chem., 2016, 6, 11, 275-290

[21] Mukhopadhyay, S., Shivankar, V., Fangueiro, R., Variability of Tensile properties in fibers extracted from pseudostem of banana plants, In: Asian Text. J., 2008, 17

[22] Mâatouk, I., et al., Numerical Simulation of Yarn Bending: Statistical Optimization, Available at: https://www. researchgate.net/publication/316476040_NUMERICAL_SIMULATION_OF_YARN_BENDING_STATISTICAL_ OPTIMIZATION [Accessed July $\left.2^{\text {nd }} 2019\right]$

[23] Williams, T., et al., Time Effects on Morphology and Bonding Ability in Mercerized Natural Fibers for Composite Reinforcement, Available at: https://www.researchgate.net/publication/228504838_Time_Effects_on_Morphology_ and_Bonding_Ability_in_Mercerized_Natural_Fibers_for_Composite_Reinforcement [Accessed July 2 ${ }^{\text {nd }}$ 2019]

[24] Msahli, S., Sakli, F., Drean, J.-Y., Study of Textile Potential of Fibres Extracted From Tunisian Agave Americana L., In: AUTEX Res. J., 2006, 6, 1, 5

[25] Jaouadi, M., M'sahli, S., Sakli, F., Optimization and Characterization of Pulp Extracted from the Agave Americana L. Fibers, In: Text. Res. J., 2009, 79, 2, 110-120

[26] Deringer, G., et al., Simultaneous optimization of several response variables, Available at: https://www. researchgate.net/publication/312977241_Simultaneous_optimization_of_several_response_variables [Accessed July $\left.2^{\text {nd }} 2019\right]$

[27] Ray, D., Sarkar, B.K., Rana, A.K., Bose, N.R., Effect of alkali treated jute fibres on composite properties, In: Bull. Mater. Sci., 2001, 24, 2, 129-1351

[28] Al-Khanbashi, A., Al-Kaabi, K., Hammami, A., Date palm fibers as polymeric matrix reinforcement: Fiber characterization, In: Polym. Compos., 2005, 26, 4, 486-497

[29] Kuruvilla, J., et al., A Review on Sisal Fiber Reinforced Polymer Composites, Available at: https://www. researchgate.net/publication/228956261_A_Review_on_Sisal_Fiber_Reinforced_Polymer_Composites [Accessed July $2^{\text {nd }}$ 2019]

[30] Rezig, S., Jaouadi, M., Khoffi, F., Msahli, S., Durand, B., Optimization of extraction process of Typha leaf fibres, In: Indian J. Fibre Text. Res., 2016, 41, 3, 242-248

[31] Mounir, J., Wanassi, B., Msahli, S., Hassen, M., Characterization of mechanical extracted Alfa fibres, In: Int J Fiber Text. Res, 2014, 4, 1-4

[32] Slah, M., Etude du potentiel textile des fibre d'agave americana L., Available at: http://www.theses.fr/06387122X [Accessed July $2^{\text {nd }}$ 2019]

[33] Dallel, M., Evaluation du potentiel textile des fibres d'Alfa (Stipa Tenacissima L.) : caractérisation physico-chimique de la fibre au fil. Mulhouse, 2012

[34] Khalil, H.P.S.A., Alwani, M.S., Omar, A.K.M., Chemical Composition, Anatomy, Lignin Distribution, and Cell Wall Structure of Malaysian Plant Waste Fibers, In: BioResources, 2006, 1, 2, 220-232

[35] Sreenivasan, S., Iyer, P.B., Iyer, K.R.K., Influence of delignification and alkali treatment on the fine structure of coir fibres (Cocos Nucifera), In: J. Mater. Sci., 1996, 31, 3, 721-726

[36] Zhao, H., Kwak, J., Conradzhang, Z., Brown, H., Arey, B., Holladay, J., Studying cellulose fiber structure by SEM, XRD, NMR and acid hydrolysis, In: Carbohydr. Polym., 2007, 68, 2, 235-241. 
[37] d'Almeida, J.R.M., Aquino, R.C.M.P., Monteiro, S.N., Tensile mechanical properties, morphological aspects and chemical characterization of piassava (Attalea funifera) fibers, In: Compos., 2006, Part A, 9, 37, 1473-1479

[38] Helbert, W., Sugiyama, J., Ishihara, M., Yamanaka, S., Characterization of native crystalline cellulose in the cell walls of Oomycota, In: J. Biotechnol., 1997, 57, 1, 29-37

[39] Rajeshkumar, G., Hariharan, V., Scalici, T., Effect of NaOH Treatment on Properties of Phoenix Sp. Fiber, In: J. Nat. Fibers, 2016, 13, 6, 702-713

[40] Mwaikambo, L.Y., Ansell, M.P., Chemical modification of hemp, sisal, jute, and kapok fibers by alkalization, In: J. Appl. Polym. Sci., 2002, 84, 12, 2222-2234

[41] Elenga, R.G., Dirras, G.F., Goma Maniongui, J., Djemia, P., Biget, M.P., On the microstructure and physical properties of untreated raffia textilis fiber, In: Compos. Part Appl. Sci. Manuf., 2009, 40, 4, 418-422

[42] Subramanian, K., Senthil Kumar, P., Jeyapal, P., Venkatesh, N., Characterization of ligno-cellulosic seed fibre from Wrightia Tinctoria plant for textile applications - an exploratory investigation, In: Eur. Polym. J., 2005, 41, 4, 853-861

[43] Åkerholm, M., Hinterstoisser, B., Salmén, L., Characterization of the crystalline structure of cellulose using static and dynamic FT-IR spectroscopy, In: Carbohydr. Res., 2004, 339, 3, 569-578

[44] Sugiyama, J., Persson, J., Chanzy, H., Combined infrared and electron diffraction study of the polymorphism of native celluloses, In: Macromolecules, 1991, 24, 9, 2461-2466

[45] Liu, W., Mohanty, A.K., Drzal, L.T., Askel, P., Misra, M., Effects of alkali treatment on the structure, morphology and thermal properties of native grass fibers as reinforcements for polymer matrix composites, In: J. Mater. Sci., 2004, 39, 3, 1051-1054

\section{Authors:}

MARWA BOUAZIZ1 ${ }^{1}$ WALID CHAOUCH ${ }^{1}$, SAOUSSEN ZANNEN ${ }^{1}$, NATHALIE LEBLANC ${ }^{2}$, MOHAMED RAGOUBI ${ }^{2}$, MOHAMED BEN HASSEN $^{3,1}$

${ }^{1}$ Laboratory of Textile Engineering, University of Monastir, Tunisia

${ }^{2}$ Transformation and Agroresources Research Unit, Institut Polytechnique Unilasalle, Rouen, France

${ }^{3}$ College of Engineering, Department of Industrial Engineering,

Taibah University, Saudi Arabia

Corresponding author:

MARWA BOUAZIZ

e-mail: marwa_bouaziz@hotmail.fr 